KA N D A I

\begin{tabular}{|l|l|l|}
\hline Volume 16 & No. 2, November 2020 & Halaman 166-182 \\
\hline
\end{tabular}

\title{
STRATEGI KESANTUNAN POSITIF PRESIDEN JOKO WIDODO DALAM PIDATONYA BERKONTEKS DIPLOMASI LUAR NEGERI (The Positive Politeness Spoken by President Joko Widodo in A Context of International Diplomacy)
}

\author{
Rangga Asmara \& Widya Ratna Kusumaningrum \\ Universitas Tidar \\ Jalan Kapten Suparman 39, Magelang, Indonesia \\ Pos-el: asmara@untidar.ac.id
}

(Diterima: 18 Desember 2019; Direvisi: 5 Mei 2020; Disetujui: 20 Mei 2020)

\begin{abstract}
This research aims to describe the positive politeness strategy spoken by President Jokowi in his speech in a context of international diplomacy. This study uses a pragmatic approach. The data were words, phrases and sentences in President Jokowi's speech at the APEC CEO Summit Forum and the Asia Africa Conference. The data were collected by using documentation and note-taking. These data were analyzed using an interactive analysis model. The results of this study indicated that President Jokowi used 13 positive politeness sub-strategies developed by Brown and Levinson (1987) in his speech in the context of international diplomacy, namely (1) paying attention to the likes, desires and needs of listeners, (2) exaggerating attention, approval, and sympathy for listeners, (3) intensifying the listener's attention by dramatizing events or facts, (4) using group identity markers (greeting, dialect, jargon, or slang), (5) seeking an agreement on a general topic by repeating parts or all of the utterances, (6) avoiding disagreement by pretending to agree, pseudo agreement, white-lies, and hedging opinions, (7) using small talk and presupposition, (8) using jokes, (9) giving offers or promises, (10) showing optimism, (11) involving speakers and listeners in the activities, (12) giving questions or asking for reasons, and (13) giving gifts (goods, sympathy, attention, cooperation) to the listener.
\end{abstract}

Keywords: positive politeness strategy, President Jokowi, diplomacy

Abstrak
Penelitian ini bertujuan mendeskripsikan strategi kesantunan positif Presiden Joko Widodo atau Jokowi dalam pidatonya berkonteks diplomasi luar negeri. Penelitian ini menggunakan ancangan pragmatis. Data dalam studi ini berupa kata, frasa, dan kalimat yang memenuhi rumusan strategi kesantunan positif yang dikembangkan oleh Brown dan Levinson (1987). Sumber data dalam penelitian ini bersumber dari video dan teks transkripsi pidato Presiden Jokowi pada Forum APEC CEO Summit dan Konferensi Asia Afrika. Pengumpulan data dalam penelitian ini menggunakan metode dokumentasi dan metode simak. Teknik analisis yang dipergunakan adalah model analisis interaktif. Hasil kajian ini menunjukkan Presiden Jokowi menggunakan tiga belas substrategi kesantunan positif yang dikembangkan oleh Brown dan Levinson dalam pidatonya berkonteks diplomasi luar negeri, yaitu (1) memperhatikan kesukaan, keinginan, dan kebutuhan pendengar, (2)membesar-besarkan perhatian, persetujuan, dan simpati kepada pendengar, (3) mengintensifkan perhatian pendengar dengan pendramatisiran peristiwa atau fakta, (4) menggunakan penanda identitas kelompok (bentuk sapaan, dialek, jargon, atau slang), (5) mencari persetujuan dengan topik yang umum atau mengulang sebagian atau seluruh ujaran, (6) menghindari ketidaksetujuan dengan pura-pura setuju, persetujuan yang semu (psedo agreement), menipu untuk kebaikan (white-lies), dan pemagaran opini (hedging opinions), (7) menggunakan basa-basi (small talk) dan presuposisi, (8) menggunakan lelucon, (9) memberikan tawaran atau janji, (10) menunjukkan keoptimisan, 
(11) melibatkan penutur dan pendengar dalam aktivitas, (12) memberikan pertanyaan atau meminta alasan, dan (13) memberikan hadiah (barang, simpati, perhatian, kerja sama) kepada pendengar.

Kata-kata kunci: strategi kesantunan positif, Presiden Jokowi, diplomasi

DOI: $10.26499 / j k . v 16 i 2.1929$

How to cite: Asmara, R., Kusumaningrum, W. R. (2020). Strategi kesantunan positif Presiden Joko Widodo dalam pidatonya berkonteks diplomasi luar negeri. Kandai, 16(2), 166-182 (DOI: 10.26499/jk.v16i2.1929)

\section{PENDAHULUAN}

Kesuksesan Barack Obama dalam meyakinkan masyarakat Amerika dipengaruhi oleh kekuatan dan kemampuan pidatonya. Tidak hanya Obama, tokoh besar lain, seperti Soekarno, Jawaharlal Nehru, Hitler, dan Napoleon mencapai sukses dan dikagumi pengikutnya juga karena gaya komunikasi dan berpidatonya. Sadar terhadap efek dan fungsi pidato cukup besar, banyak tokoh yang menggunakan pidato sebagai media yang efektif untuk menyampaikan ide, gagasan, dan mempengaruhi masyarakat (Asmara, 2016; Asror, 2015). Bahkan, pidato dikatakan sebagai bentuk penggalangan kekuasaan melalui media massa dengan memanfaatkan fitur-fitur linguistik (Asror \& Sholehhudin, 2016; Sobur, 2006). Melalui pidato di media massa, seseorang berusaha membujuk masyarakat dengan persuasinya (Sulistyaningtyas, 2009).

Pidato sebagai sebuah teks adalah satu sistem tanda yang merefleksikan sikap, keyakinan, dan nilai-nilai tertentu (Noermanzah et al., 2017; Sulityaningtyas et al., 2014). Setiap pesan dalam pidato memiliki dua tingkatan makna, yaitu makna yang dikemukakan secara eksplisit di permukaan dan makna yang dikemukakan secara implisit di balik pidato (Asmara, 2016; Luhukay, 2007).

Pidato Presiden Joko Widodo (Jokowi) pada forum-forum berskala internasional menarik untuk dicermati dan dikaji. Dua pidato yang menarik untuk dibahas secara mendalam dari perspektif retorika dan pragmatik adalah pidato Presiden Jokowi pada Forum APEC CEO Summit di Beijing, Tingkok, 10 November 2014 dan Konferensi Asia Afrika (KAA) di Jakarta, 22 April 2015. Meskipun dua forum tersebut membahas isu yang berbeda, tetapi Jokowi tampak menggunakan strategi yang sama dalam berdiplomasi. Hal tersebut dapat dilihat dari dua aspek retorika, yaitu (1) peran dan posisi aktor dan (2) gagasan yang ditampilkan dengan menggunakan pilihan kata, kalimat, dan wacana yang dirangkainya untuk membangun tujuan tertentu (Nasiha \& Yunaldi, 2019; Sobur, 2006).

Sebagai salah satu bentuk praktik retorika dan pragmatik, pidato Jokowi bukan hanya dipandang dari persoalan linguistik semata, tetapi sebagai bentuk ekspresi ideologi (Asmara et al., 2020). Tujuan diplomasi Jokowi dalam pidatonya lebih pada upayanya mempersuasi audiensnya untuk membentuk pendapat umum mengenai identitas atau citra dirinya dan Indonesia. Dari sudut pandang kewacanaan, pidato Jokowi juga dianggap memenuhi tiga aspek kewacanaan, yakni (1) isi, yaitu hal-hal yang diucapkan atau dilakukan, (2) relasi, yaitu hubungan sosial yang dimasukkan dalam wacana, dan (3) subjek atau posisi yang ditempati seseorang (Asror, 2015; Sobur, 2006).

Jokowi bukan politikus yang pandai bicara. Gaya pidato Jokowi meskipun tertulis dan dibacakan, tetaplah terasa lisan. Spontanitasnya 
mencerminkan kepribadian seorang yang tumbuh dari bawah. Gaya Jokowi ini memang berbeda dengan para presiden Indonesia sebelumnya. Untuk dapat mempersuasi dan merebut simpati, Jokowi memainkan strategi dan metode berpidato yang berbeda dengan gaya presiden-presiden yang lainnya.

Penelitian tentang praktik retorika dalam pidato presiden telah dilakukan oleh Luhukay (2007) yang menganalisis teks pidato Presiden SBY dengan pendekatan retorika Aristoteles. Luhukay memaparkan dari lima hukum retorika yang dikemukakan oleh Aristoteles yang paling dominan dalam teks pidato Presiden SBY dalam pembukaan Musyawarah Kebangsaan 2007 adalah elocutio (gaya). Dalam teks pidato Presiden SBY, sisi yang paling diangkat untuk mempengaruhi audiensi adalah ethos. Menurut Aristoteles, sisi ethos terdapat di dalam bagian pengantar yang bertujuan untuk menumbuhkan kredibilitas si komunikator. Ada tiga aspek dalam ethos, yakni intelegensi, karakter, dan goodwill.

Penelitian tentang strategi kebahasaan dalam pidato Jokowi juga pernah diteliti oleh Asmara (2016). Penelitian ini bertujuan mendeskripsikan strategi kebahasaan Presiden Jokowi dalam menanamkan ideologi dan manifesto pemerintahan. Asmara (2016) menggunakan analisis wacana kritis model Van Dijk. Sumber data penelitian adalah teks pidato Presiden Jokowi berjudul "Di Bawah Kehendak Rakyat dan Konstitusi". Pengumpulan data menggunakan analisis dokumen dengan menelusuri struktur mikro dan makro. Hasil penelitiannya menunjukkan bahwa terdapat empat strategi kebahasaan, yaitu strategi leksikon, stilistika, pronomina, dan sintaksis. Pada strategi leksikon dan stilistika ditemukan kosakata yang bervisi kelautan dan kerja sehingga membedakannya dengan presiden sebelumnya dan mencitrakan diri sebagai penjelmaan Soekarno. Pada strategi pronomina, Jokowi berusaha mengacaukan struktur dan mengaburkan makna pronomina: saya, kami, kita, dan rakyat sehingga membangkitkan kemenyatuan antara penutur dan mitra tutur (audiensi). Pada strategi sintaksis digunakan kalimat positif dan negatif untuk menokohkan diri (glorifikasi).

Penelitian tentang tindak kesantunan berbahasa khususnya strategi bertutur pada komentar akun Instagram Jokowi juga telah dilakukan oleh Kusmanto, Prayitno, dan Ngalim (2019). Studi ini bertujuan mendeskripsikan strategi kesantunan berbahasa yang digunakan warganet dalam berkomentar pada akun Instagram Jokowi. Data dalam studi ini berupa kata, frasa, dan kalimat yang memiliki nilai kesantunan positif dan negatif komentar pada akun Instagram Jokowi. Sumber data dalam studi ini adalah komentar-komentar pada akun Instagram Jokowi. Pengumpulan data dalam studi ini menggunakan metode dokumentasi dan simak dilanjutkan teknik bebas libat cakap (SBLC). Analisis data dalam studi ini menggunakan padan intralingual dan padan pragmatis. Hasil studi ini menunjukkan bahwa strategi kesantunan warganet dalam berkomentar pada akun Instagram Jokowi direalisasikan dengan dua strategi, yaitu strategi kesantunan positif dan negatif.

Strategi kesantunan positif direalisasikan menjadi sembilan wujud, yaitu memberikan perhatian, menunjukkan sikap optimis, menggunakan penanda indentitas, memberikan pertanyaan, melibatkan penutur dalam komunikasi, mengintensifkan perhatian penutur dengan cara mendramatisasi peristiwa dan fakta, memperhatikan keinginan mitra tutur, memberikan janji, dan menggunakan lelucon. 
Strategi kesantunan negatif direalisasikan menjadi tiga bentuk, yaitu meminta maaf, menunjukkan sikap pesimis, dan menggunakan bentuk impersonal. Hal ini menunjukkan bahwa warganet pada akun Instagram Jokowi memiliki kepercayaan terhadap kepemimpinan Jokowi.

Berangkat dari dasar kajian wacana dalam pidato Jokowi, permasalahan utama dalam penelitian ini adalah bagaimanakah strategi kesantunan positif Presiden Joko Widodo dalam pidatonya berkonteks diplomasi luar negeri? Tujuan khusus penelitian ini diharapkan dapat mengulas secara detail strategi retorika yang memuat kesantunan positif. Penelitian ini menawarkan horizon baru berupa gaya berpidato atau berdiplomasi atau berpersuasi di depan publik model Jokowi. Gaya berpidato yang terkesan santai dalam menyampaikan gagasannya seolah-olah menjadikan pidato kenegaraan yang lazimnya serius sebagai pembahasan santai. Namun, gaya komunikasi pidatonya yang semiformal diduga mengantarkan kedekatan dengan pendengarnya.

\section{LANDASAN TEORI}

Brown \& Levinson (1987) memostulatkan empat dasar strategi bertutur untuk menjaga muka atau harga diri, yaitu (1) melakukan tindak tutur secara langsung/apa adanya tanpa basabasi (bald on record), (2) melakukan tindak tutur dengan menggunakan strategi kesantunan positif, (3) melakukan tindak tutur dengan menggunakan strategi kesantunan negatif, dan (4) melakukan tindak tutur secara tersamar/tidak langsung.

Berkaitan dengan strategi kesantunan negatif, Brown \& Levinson (1987) membagi kesantunan negatif menjadi sepuluh substrategi yang meliputi, (1) ungkapan secara tidak langsung, (2) menggunakan pagar, (3) bersikap pesimis dengan cara bersikap hati-hati, (4) meminimalkan pembebanan terhadap lawan tutur, (5) menyatakan rasa hormat, menggunakan permohonan maaf, (7) jangan menyebutkan penutur dan lawan tutur, (8) menyatakan face threatening act (FTA) sebagai suatu kaidah sosial yang umum berlaku, (9) nominalisasikan pernyataan, dan (10) menyatakan secara jelas bahwa penutur telah memberikan kebaikan (hutang) atau tidak kepada lawan tutur.

Berbeda dengan strategi kesantunan negatif, Brown \& Levinson (1987) menjabarkan kesantunan positif menjadi lima belas substrategi, yaitu (1) memperhatikan kesukaan, keinginan, dan kebutuhan pendengar; membesar-besarkan perhatian, persetujuan, dan simpati kepada pendengar; (3) mengintensifkan perhatian pendengar dengan pendramatisiran peristiwa atau fakta; (4) menggunakan penanda identitas kelompok (bentuk sapaan, dialek, jargon, atau slang); (5) mencari persetujuan dengan topik yang umum atau mengulang sebagian atau seluruh ujaran; (6) menghindari ketidaksetujuan dengan pura-pura setuju, persetujuan yang semu (psedo agreement), menipu untuk kebaikan (white-lies), pemagaran opini (hedging opinions); (7) menggunakan basa-basi (small talk) dan presuposisi; (8) menggunakan lelucon; menyatakan paham akan keinginan pendengar; (10) memberikan tawaran atau janji; (11) menunjukkan keoptimisan; (12) melibatkan penutur dan pendengar dalam aktivitas; (13) memberikan pertanyaan atau meminta alasan; (14) menyatakan hubungan secara timbal balik (resiprokal); dan (15) memberikan hadiah (barang, simpati, 
perhatian, kerja sama) kepada pendengar.

\section{METODE PENELITIAN}

Penelitian ini menggunakan ancangan pragmatik dengan mendasarkan pijakan analisisnya pada fungsi-fungsi bahasa (language functions). Data yang dianalisis bersumber dari video dan teks transkripsi pidato Presiden Jokowi pada Forum APEC CEO Summit di Beijing, Tingkok, 10 November 2014, berdurasi tiga belas menit dan Konferensi Asia Afrika di Jakarta, 22 April 2015, berdurasi sebelas menit.

Adapun metode yang digunakan peneliti dalam menjaring data adalah metode dokumentasi. Pada metode ini, peneliti mengumpulkan data dengan mengunduh video dan salinan teks pidato Presiden Jokowi yang diunggah pada laman youtube.com dan www.setkab.go.id. Penyediaan data juga dilakukan dengan metode simak yang kemudian dilanjutkan dengan teknik catat.

Berdasarkan metode pengumpulan data yang digunakan dalam penelitian ini, instrumen yang digunakan peneliti adalah (1) peneliti sendiri, (2) pedoman dokumentasi, dan (3) pedoman wawancara.

Pemeriksaan keabsahan data penelitian ini dilakukan dengan membaca, mengecek, dan mengintensifkan analisis data. Untuk menjamin dan mengembangkan validitas data, digunakan teknik trianggulasi data/sumber, yaitu mengumpulkan data sejenis dari beberapa sumber data yang berbeda dan trianggulasi peneliti, yaitu mendiskusikan temuan yang diperoleh dengan pakar di bidangnya. Penggunaan triangulasi data/sumber dan triangulasi peneliti diharapkan makin meningkatkan kesahihan atau validitasnya.
Teknik analisis yang dipergunakan dalam penelitian ini adalah model analisis interaktif. Tiga komponen pokok analisis (reduksi data, sajian data, dan penarikan simpulan) aktivitasnya dapat dilakukan dengan cara interaksi, baik antar komponennya, maupun dengan proses pengumpulan data, dalam proses yang berbentuk siklus (Huberman \& Miles, 2012).

Data dalam penelitian ini juga dianalisis dengan metode padan intralingual dan padan pragmatis. Metode padan intralingual digunakan untuk mengklasifikasi dan mengidentifikasi data kebahasaan yang memuat strategi kesantunan positif, sedangkan metode padan pragmatis digunakan untuk menginterpretasi maksud/motif di balik strategi kesantunan positif yang digunakan, berdasarkan konteks situasi dan latar wacana yang relevan.

\section{PEMBAHASAN}

Strategi retorika positif Presiden Jokowi diklasifikasi berdasarkan strategi kesantunan positif yang dikembangkan oleh Brown dan Levinson. Berdasarkan hasil analisis, Jokowi menggunakan tiga belas substrategi kesantunan positif dalam pidatonya berkonteks diplomasi luar negeri, yaitu (1) memperhatikan kesukaan, keinginan, dan kebutuhan pendengar, (2) membesar-besarkan perhatian, persetujuan, dan simpati kepada pendengar, (3) mengintensifkan perhatian pendengar dengan pendramatisiran peristiwa atau fakta, (4) menggunakan penanda identitas kelompok (bentuk sapaan, dialek, jargon, atau slang), (5) mencari persetujuan dengan topik yang umum atau mengulang sebagian atau seluruh ujaran, (6) menghindari ketidaksetujuan dengan pura-pura setuju, persetujuan yang semu (psedo agreement), menipu untuk 
kebaikan (white-lies), dan pemagaran opini (hedging opinions), (7) menggunakan basa-basi (small talk) dan presuposisi, (8) menggunakan lelucon, (9) memberikan tawaran atau janji, (10) menunjukkan keoptimisan, melibatkan penutur dan pendengar dalam aktivitas, (12) memberikan pertanyaan atau meminta alasan, dan (13) memberikan hadiah (barang, simpati, perhatian, kerja sama) kepada pendengar.

\section{Realisasi Strategi Memperhatikan Kesukaan, Keinginan, dan Kebutuhan Pendengar}

Realisasi strategi retorika positif memperhatikan kesukaan, keinginan, dan kebutuhan pendengar dalam pidato Presiden Jokowi berkonteks diplomasi luar negeri tampak pada data (1) sampai dengan (4).

(1) Oleh sebab itu, kerja sama antara Tiongkok dan Indonesia itu harus menguntungkan kedua negara. Harus menguntungkan rakyat Indonesia dan rakyat Tiongkok. Tidak mungkin hanya salah satu saja. Semuanya harus mendapatkan keuntungan (APEC).

(2) Inilah yang nanti juga akan saya sampaikan kepada Presiden Xi Jinping yang sebentar lagi akan bertemu, bahwa kerja sama ini memang perlu diperkuat lagi, tetapi keuntungan harus berada di dua negara dan di kedua rakyat kita (APEC).

Pada data (1) dan (2) secara lugas Jokowi menyampaikan manfaat kerja sama investasi kedua negara adalah bagi kedua negara. Jokowi berusaha mengedepankan unsur ini dalam paparannya karena akan dianggap si penutur berusaha memperhatikan kesukaan, keinginan, dan kebutuhan pendengar, yang notabene adalah para investor dari Tiongkok. Dengan berinvestasi, tentu yang dicari para investor tersebut adalah keuntungan. Bahkan, keuntungan sebesar-besarnya dari Indonesia. Di awal pidato, Jokowi telah memberikan gambaran kekayaan SDA dan SDM Indonesia. Para investor pasti ingin mengambil keuntungan dari SDA dan SDM Indonesia.

(3) Nah, ini tadi yang sudah saya sampaikan. Untuk perizinan akan kita satukan. Saya sudah targetkan dalam tiga sampai enam bulan ini harus selesai sehingga perizinan nantinya semuanya dalam keadaan yang cepat, ada kepastian, bayarnya juga jelas, selesainya juga jelas sehingga mulai proyek itu juga jelas kapan dan kalau ada masalah bisa telepon ke menteri. Ini Pak Menko Perekonomian juga ada di sini, menteri perdagangan juga di sini, telepon ke beliau. Kalau masih tidak ditanggapi telepon ke presiden langsung (APEC).

(4) Dunia yang kita warisi sekarang masih sarat dengan ketidakdilan, kesenjangan, dan kekerasan global. Cita-cita bersama mengenai lahirnya sebuah peradaban baru, sebuah tatanan dunia baru berdasarkan keadilan, kesetaraan, dan kemakmuran masih jauh dari harapan. Ketidakadilan dan ketidakseimbangan global masih terpampang di hadapan kita (KAA).

Jokowi tahu apa yang dibutuhkan oleh para investor, apalagi investor luar negeri. Sebagaimana paparannya pada data (3), dia tampak menguasai kendala umum yang dihadapi para investor selama ini adalah seputar perizinan. Dengan memberikan kepastian soal perizinan, Jokowi berusaha memberikan servis sebaik-baiknya pada calon investornya. Dia tahu betul kesukaan, 
keinginan, dan kebutuhan calon investornya.

Pada data (4), Jokowi tampak memahami keinginan dan kebutuhan audiensinya melalui forum ini, yaitu cita-cita bersama mengenai lahirnya sebuah peradaban baru, sebuah tatanan dunia baru berdasarkan keadilan, kesetaraan, dan kemakmuran. Dia tahu betul gagasan Soekarno mengadakan KAA, yaitu membangkitkan kesadaran bangsa-bangsa di Asia dan Afrika untuk mendapatkan hak hidup sebagai bangsa merdeka-yang menolak ketidakadilan dan yang menentang segala bentuk imperialisme.

\section{Realisasi Strategi Membesar- Besarkan Perhatian, Persetujuan, dan Simpati kepada Pendengar}

Realisasi strategi retorika positif membesar-besarkan perhatian, persetujuan, dan simpati kepada pendengar dalam pidato Presiden Jokowi berkonteks diplomasi luar negeri tampak pada data (5) dan (6).

(5) Artinya, lima belas tahun kemudian tujuh tahun berhenti hanya gara-gara pembebasan tanah. Ini tidak boleh lagi terjadi di masa yang akan datang. Investasi, baik jalan tol, baik power plant, baik apapun yang berkaitan dengan pertumbuhan ekonomi, apapun yang berkaitan dengan pembukaan lapangan pekerjaan, pemerintah pusat, pemerintah provinsi, pemerintah daerah harus semuanya membantu. Ini tekad kita agar pertumbuhan ekonomi kita ke depan bisa kembali tumbuh dengan baik (APEC).

(6) Atas nama rakyat dan pemerintah Indonesia saya ucapkan selamat datang di Indonesia, negara penggagas dan tuan rumah KAA 1955. Enam puluh tahun lalu Bapak Bangsa kami, Presiden Soekarno,
Bung Karno, mencetuskan gagasan tersebut demi membangkitkan kesadaran bangsa-bangsa Asia dan Afrika untuk mendapatkan hak hidup sebagai bangsa merdeka yang menolak ketidakadilan, yang menentang segala bentuk imperialisme (KAA).

Pada data (5), Jokowi sebagai presiden tampak mengintruksikan semua jajarannya untuk membantu pertumbuhan ekonomi melalui investasi. Permasalahan calon investor dalam berinvestasi tidak hanya menyangkut pemerintah pusat, tetapi juga dari pemerintah daerah. Jokowi tampak ingin memberikan perhatian besar pada pelayanan para investor. Kalimat "Ini tidak boleh lagi terjadi di masa yang akan datang" pada data (5) bermakna ia memberi persetujuan untuk mempermudah masuknya investasi. Investasi tidak boleh terhambat oleh masalah semacam pembebasan tanah.

Pada data (6), Jokowi berusaha mencari persetujuan terhadap gagasan diadakannya KAA. Ia tahu betul dengan menempatkan wacana ini di awal pidato dapat memancing persetujuan audiensi.

\section{Realisasi Strategi Mengintensifkan Perhatian Pendengar dengan Pendramatisiran Peristiwa atau Fakta}

Realisasi strategi retorika positif mengintensifkan perhatian pendengar dengan pendramatisiran peristiwa atau fakta dalam pidato Presiden Jokowi berkonteks diplomasi luar negeri tampak pada data (7) sampai dengan (10).

(7) Agar kita tahu semuanya, bahwa dua pertiga wilayah Indonesia adalah laut, adalah air, adalah samudera. Penduduk di Indonesia 240 juta dan jarak dari barat ke timur Indonesia itu seperti London sampai Istanbul, sebuah jarak yang sangat lebar 
sekali. Kemudian investasi di triwulan pertama kemarin, investasi ke Indonesia mencapai Rp106 triliun atau kurang lebih 9 miliar USD, sebuah angka yang lumayan besar (APEC).

Pada data (7) Jokowi menggunakan strategi yang dapat mengintensifkan perhatian audiensinya dengan menyajikan sejumlah fakta tentang Indonesia. Data dua pertiga wilayah Indonesia adalah laut tentu membawa pesan bahwa dalam laut Indonesia tersimpan kekayaan yang luar biasa. Jokowi juga menyajikan data jumlah penduduk Indonesia yang besar. Informasi ini tentu memancing para investor Tiongkok untuk berinvestasi ke Indonesia. Investor Tiongkok tentu ingin mendapatkan keuntungan yang sebesarbesarnya dari kelebihan SDA dan SDM yang dimiliki oleh Indonesia. Dengan menunjukkan angka capaian investasi yang menurutnya lumayan besar, para audien ingin ditunjukkan bahwa sudah banyak telah berinvestasi ke Indonesia. Kalimat deklaratif tersebut berimplikasi, selain ingin menunjukkan prestasi di bidang ekonomi juga bentuk undangan untuk segera berinvestasi.

(8) Saya berikan contoh di Jakarta. Ada yang namanya Jakarta Outer Ring Road. Lima belas tahun yang lalu dibangun. Tujuh tahun yang lalu stop, berhenti, karena masalah 1,5 kilometer, karena masalah 143 keluarga yang tidak menerima kompensasi ganti rugi. Tahun yang lalu saya datangi langsung ke bawah. empat kali saya undang makan, akhirnya selesai masalah itu. Rampung. Hanya dalam waktu empat bulan, tapi proyek itu sudah berhenti tujuh tahun dan enam bulan yang lalu sudah digunakan (APEC).

Bagi seorang presiden, suatu masalah yang kompleks sepertinya akan menjadi mudah apabila ia mau turun tangan langsung menyelesaikannya. Hal inilah yang tampak pada data (8), yaitu upaya Jokowi dalam mengatasi masalah yang sudah bertahun-tahun mangkrak di Indonesia. Dia menyajikan narasi yang sangat meyakinkan dengan mengatakan "Empat kali saya undang makan, akhirnya selesai masalah itu. Rampung." Tentunya tidak ada yang mustahil bagi seorang presiden. Dia sengaja mendramatisasi bahasanya untuk mendapatkan perhatian pendengarnya.

(9) Yang terakhir masalah kualitas. Masalah kualitas, kita ini sudah bekerja Tiongkok dengan Indonesia, ini sudah lama, tetapi masalah kualitas saya harus ngomong apa adanya, harus diperbaiki. Kesalahannya ada di dua dunia usaha, yang di sini maupun yang di Indonesia. Saya berikan contoh power plant. Kualitas yang sekarang ada, yang sudah dibangun, itu kualitasnya kurang baik. Kurang baik, ini yang harus diperbaiki. Ke depan, kita masih banyak perlu power plant, tapi saya minta karena ada yang baik, ada yang cukup, ada yang tidak baik. Nah, yang tidak baik dan yang cukup dihilangi, yang dibangun nanti semuanya yang baik (APEC).

Pada data (9), Jokowi tampak kecewa dengan kualitas power plant yang dibangun saat ini. Power plant yang digunakan sekarang adalah produk dari Tiongkok. Jokowi tidak sepenuhnya menyalahkan para pebisnis Tiongkok karena kesalahan ada pada dua negara.

(10) Ketika negara-negara kaya yang hanya sekitar dua puluh persen penduduk dunia, menghabiskan tujuh puluh persen sumber daya bumi maka ketidakadilan menjadi nyata. Ketika ratusan orang di belahan bumi sebelah utara 
menikmati hidup super kaya, sementara 1,2 miliar penduduk dunia di sebelah selatan tidak berdaya dan berpenghasilan kurang dari dua dolar per hari, maka ketidakadilan semakin kasat mata (KAA).

Untuk menarik perhatian audiensinya, Jokowi menyajikan sebuah data yang dapat dikatakan mencengangkan sebagaimana tampak pada data (10). Dia tahu betul, data tersebut sangat membantunya untuk membangkitkan "rasa persatuan" di antara negara-negara anggota KAA karena pada umumnya mengalami gejala yang relatif sama, yaitu kesenjangan ekonomi-perbedaan pendapatan masyarakat di negara-negara bagian utara dan selatan.

\section{Realisasi Strategi Menggunakan Penanda Identitas Kelompok}

Realisasi strategi retorika positif menggunakan penanda identitas kelompok dalam pidato Presiden Jokowi berkonteks diplomasi luar negeri tampak pada data (11) sampai dengan (14).

(11) Karena beberapa tahun yang lalu saya adalah seorang pengusaha. Jadi, kalau hari ini berada di tengahtengah bapak ibu semuanya untuk berbicara masalah bisnis, untuk berbicara investasi itu memang dunia saya sebelum saya jadi wali kota, sebelum saya jadi gubernur, dan juga sebelum saya jadi presiden saat ini (APEC).

Pada data (11) Jokowi tampak ingin menunjukkan dirinya sebagai bagaian dari audiensinya. Dengan menunjukkan kesamaan identitas sebagai pengusaha, Jokowi ingin menunjukkan kedekatan dengan audiensi. Strategi ini sangat efektif disampaikan di awal pidato karena dapat merebut perhatian dan simpati dari audiensinya.

(12) Nah, ini kita yang masalah. Saat ini kita memang kekurangan listrik. Tidak di Sumatera, tidak di Kalimantan, tidak di Sulawesi dan juga di Papua. Masalah besar (APEC).

(13) Enam puluh tahun lalu, solidaritas Asia-Afrika, kita kumandangkan untuk memperjuangkan kemerdekaan, untuk menciptakan kesejahteraan dan untuk memberi keadilan bagi rakyat kita. Itulah gelora KAA 1955. Itulah esensi semangat Bandung (KAA).

(14) Kita harus bekerjasama menghadapi ancaman kekerasan, pertikaian, dan radikalisme seperti ISIS. Kita harus melindungi hak-hak rakyat kita. Kita harus menyatakan perang pada narkoba yang menghancurkan masa depan anak-anak kita (KAA).

Pada data (12) sampai dengan (14) Jokowi lebih memilih menggunakan pronomina "kita" daripada "kami". Pronomina adalah kategori yang berfungsi untuk menggantikan nomina (Kridalaksana, 2008). Pemilihan pronomina "kita" oleh Jokowi tampak dia gunakan untuk membangun kesamaan identitas kolektif, meskipun antara Jokowi dan audiensi berasal dari dua negara yang berbeda. Masalah yang ia hadapi adalah masalahnya dan masalah rakyatnya tidak melibatkan para audiensi yang merupakan investor dari Tiongkok. Penggunaan pronomina "kita" secara sengaja untuk mengacaukan subjek dan objek sebuah kalimat sehingga pendengar rancu (Asmara, 2016).

Dalam kajian pragmatik, kata kita merupakan bentuk inklusif atau gabungan antara persona pertama (aku, daku, saya) dan kedua (kamu, kau, dikau). Secara sederhana, kita berarti 
saya dan anda atau kami dan anda. Asror \& Sholehhudin (2016) mengemukakan bahwa kata ganti (pronomina) merupakan aspek yang dapat dimanipulasi dengan pilihan bahasa untuk menciptakan makna imajinatif. Kata ganti "saya" dan "kami" digunakan untuk menggambarkan sikap resmi komunikator semata-mata (Rindu, 2017). Kata ganti "kita" merupakan representasi dan wujud sikap bersama dalam satu komunitas (Asror \& Sholehhudin, 2016). Potensi kata ganti "kita" telah disadari politisi dapat membangkitkan sensasi persatuan. Oleh karena itulah, kata ini banyak digunakan sebagai sarana retorika.

\section{Realisasi Strategi Mencari Persetujuan dengan Topik yang Umum atau Mengulang Sebagian atau Seluruh Ujaran}

Realisasi strategi retorika positif mencari persetujuan dengan topik yang umum atau mengulang sebagian atau seluruh ujaran dalam pidato Presiden Jokowi berkonteks diplomasi luar negeri tampak pada data (15) sampai dengan (18).

(15) Ke depan, karena kita ingin agar transportasi untuk logistik dan orang itu lebih murah kita ingin membangun jalur rel kereta api tidak hanya di Pulau Jawa tetapi juga di Sumatera, di pulau Kalimantan, di pulau Sulawesi dan di Papua. Oleh sebab itu, kita membutuhkan investasi yang besar di dalam membangun jalur kereta api. Inilah kesempatan Bapak/Ibu semuanya untuk masuk ke investasi ini.

Kemudian airport. Kita juga membutuhkan airport karena airport-airport yang ada di Indonesia runway-nya masih pendek, kemudian terminalnya juga masih kecil-kecil dan kita ingin lima tahun ke depan airport yang ada semuanya diperluas dan yang belum, tentu saja dibangun. Ini juga peluang kesempatan yang bisa Bapak/Ibu masuki.

Lima tahun ke depan kita ingin membangun dan memperluas 24 pelabuhan. Seaport dan deep seaport untuk memperlancar arus barang baik ke luar negeri maupun antarpulau. Ini juga kesempatan yang bisa Bapak/Ibu masuki dalam memperbaiki infrastruktur yang ada di Indonesia (APEC).

(16) Kemudian juga masalah kilang. Masalah refinery. Ini juga kesempatan bagi Bapak/Ibu semuanya yang ingin masuk ke sini, karena sudah bertahun-tahun kita tidak memperbaiki kilang kita (APEC).

Pada data (15) dan (16) tampak Jokowi mengulang-ulang kalimat "Inilah kesempatan Bapak/Ibu semuanya untuk masuk ke investasi ini". Dia sengaja mengulang-ulang kalimat tersebut karena topik utama pidato Jokowi ini adalah menjalin kerja sama investasi dari para investor dari Tiongkok. Jokowi menyampaikan secara lugas kepada audiensi bahwa Indonesia butuh infrastruktur berkaitan transportasi. Jokowi juga mengajak para investor untuk berinvestasi meski tidak secara eksplisit menggunakan kode lingual mengajak.

(17)Dunia yang kita warisi sekarang masih sarat dengan ketidakdilan, kesenjangan, dan kekerasan global. Cita-cita bersama mengenai lahirnya sebuah peradaban baru, sebuah tatanan dunia baru berdasarkan keadilan, kesetaraan, dan kemakmuran, masih jauh dari harapan. Ketidakadilan dan ketidakseimbangan global masih terpampang di hadapan kita (KAA). 
(18) Hari ini dan esok kita berkumpul di Jakarta untuk menjawab tantangan ketidakadilan dan ketidakseimbangan itu. Hari ini dan esok, rakyat kita menanti jawaban terhadap persoalan-persoalan yg mereka hadapi (KAA).

Pada data (17), Jokowi mengulang-ulang kata ketidakadilan. Kata ini memang menjadi akar permasalahan lahirnya KAA. Dia berusaha membangkitkan semangat KAA enam puluh tuhun yang lalu. Pada data (18), Jokowi mengulang-ulang kata "hari ini" dan "esok". Kata "hari ini" dan "esok", dia ulang untuk menunjukkan pentingnya pertemuan dua hari ini.

\section{Realisasi Strategi Menghindari Ketidaksetujuan dengan Pura-Pura Setuju, Persetujuan yang Semu (Psedo Agreement), Menipu untuk Kebaikan (White-Lies), dan Pemagaran Opini (Hedging Opinions)}

Realisasi strategi retorika positif menghindari ketidaksetujuan dengan pura-pura setuju, persetujuan yang semu (psedo agreement), menipu untuk kebaikan (white-lies), dan pemagaran opini (hedging opinions) dalam pidato Presiden Jokowi berkonteks diplomasi luar negeri tampak pada data (19) sampai dengan (23).

(19) Ini kesempatan kerja sama antara Tiongkok dan Indonesia dan jalinan kerja sama itu kan bukan hanya setahun-dua tahun yang lalu. Sudah beratus-ratus yang lalu kita bekerja sama antara Tiongkok dan Indonesia (APEC).

Pada data (19), Jokowi tampak mempraktikkan strategi retorika semacam menipu untuk kebaikan (whitelies). Kalimat "Sudah beratus-ratus yang lalu kita bekerja sama antara Tiongkok dan Indonesia”. Lebih semacam justifikasi untuk memaksa pemerintah Tiongkok dan para investor Tiongkok bekerja sama dan berinvestasi. Jokowi sepertinya tidak memiliki argumen yang sangat kuat selain gambaran masa lalu, para pedagang Tiongkok ke Indonesia untuk berdagang.

(20)Kemudian juga perlu saya sampaikan masalah yang berkaitan dengan minerba. Masalah yang berkaitan dengan raw material yang ada di Indonesia. Kita akan mulai keluar dari Indonesia itu barang setengah jadi, minimal barang setengah jadi dan barang jadi. Karena kita ingin nilai tambah itu ada di Indonesia. Oleh sebab itu, kerja sama antara Tiongkok dan Indonesia itu harus menguntungkan kedua negara. Harus menguntungkan rakyat Indonesia dan rakyat Tiongkok. Tidak mungkin hanya salah satu saja. Semuanya harus mendapatkan keuntungan (APEC).

(21) Yang terakhir masalah kualitas. Masalah kualitas, kita ini sudah bekerja Tiongkok dengan Indonesia, ini sudah lama. Tetapi masalah kualitas saya harus ngomong apa adanya, harus diperbaiki. Kesalahannya ada di dua dunia usaha, yang di sini maupun yang di Indonesia. Saya berikan contoh power plant. Kualitas yang sekarang ada, yang sudah dibangun, itu kualitasnya kurang baik. Kurang baik, ini yang harus diperbaiki. Ke depan, kita masih banyak perlu power plant, tapi saya minta, karena ada yang baik, ada yang cukup, ada yang tidak baik. Nah, yang tidak baik dan yang cukup dihilangi, yang dibangun nanti semuanya yang baik (APEC).

(22) Produk-produk seperti itu memang harus dilihat kualitasnya sehingga jangan sampai, kita juga ingin 
menjaga agar persepsi, agar image, barang yang berasal dari Tiongkok itu memang betul-betul barangbarang yang memang baik. Karena saya tahu, memang produknya di sini banyak yang baik, tetapi kadang-kadang, yang di Indonesia juga minta yang tidak baik, tetapi dibayar dengan harga yang baik. Ini yang enggak benar. Waktu jadi gubernur juga sama. Bus itu juga sama. Saya kira Bapak/Ibu semuanya tahu. ini sudah tidak boleh kejadian lagi. Ke depan, semuanya harus barang-barang yang mempunyai kualitas (APEC).

(23) Saya berpendirian pengelolaan ekonomi dunia tidak bisa hanya diserahkan kepada ketiga lembaga keuangan internasional itu. Kita wajib membangun sebuah tatanan ekonomi baru yang terbuka bagi kekuatan-kekuatan ekonomi baru. Kita mendesak dilakukannya reformasi arsitektur keuangan global untuk hilangkan dominasi kelompok negara atas negara-negara lain (KAA).

Jokowi kembali memberi penguatan pada audiensi dengan menggunakan strategi pemagaran opini (hedging opinions). Penggunaan modalitas epistemik dengan penanda lingual "harus" pada data (20) dan (21) serta "wajib" pada data (22) dan (23) memberi efek memaksa secara halus untuk berkerja sama, berinvetasi, dan membangun tatanan ekonomi baru. Dia berulang kali menggunakan penanda modalitas epistemik sebagai bentuk pemagaran opini atau misinya.

Pada data (22) Jokowi secara lugas menyebut produk-produk Tiongkok memiliki kualitas baik. Hal ini kontradiktif dengan pernyataannya pada data (21) ketika mengulas kualitas power plant dari Tiongkok. Dia tampak sedang memperagakan strategi retorika positif menghindari ketidaksetujuan dengan pura-pura setuju atau persetujuan yang semu (psedo agreement). Dia tampak mengurangi beban petuturnya dan memperbanyak beban pada diri sendiri. Sebagaimana tampak pada kalimat "Tetapi kadang-kadang, yang di Indonesia juga minta yang tidak baik". Hal ini semata-mata dia lakukan agar misinya untuk mendapatkan investasi dari Tiongkok tercapai.

\section{Realisasi Strategi Menggunakan Basa- Basi (Small Talk) dan Presuposisi}

Realisasi strategi retorika positif menggunakan basa-basi (small talk) dan presuposisi dalam pidato Presiden Jokowi berkonteks diplomasi luar negeri tampak pada data (24) sampai dengan (26).

(24) Yang saya hormati, bapak ibu dari dunia usaha, baik yang berasal dari Indonesia maupun dari Tiongkok. Pagi hari ini saya berbahagia sekali, saya sangat senang karena bisa hadir di tengah-tengah bapak ibu semuanya karena beberapa tahun yang lalu saya adalah seorang pengusaha (APEC).

Pada data (24) tampak Jokowi menggunakan basa-basi dalam memulai pidatonya. Basa-basi Jokowi ditandai dengan penggunaan salam dan menyampaikan perasaannya. Penggunaan salam pada konteks pidato merupakan sesuatu yang lazim untuk mengawali pidato sehingga bisa dianggap mengujarkan salam pada petuturnya hanya sekadar berbasa-basi. Jokowi juga menggunakan basa-basi dengan mengutarakan perasaannya kepada petuturnya. Pada klausa "Pagi hari ini saya berbahagia sekali, saya sangat senang", tampak Jokowi berbasabasi karena informasi utamanya bukanlah tentang perasaannya itu 
melainkan ia ingin menunjukkan bahwa dia adalah juga seorang pengusaha.

(25) Saat ini dunia membutuhkan kepemimpinan global yang kolektif, yang dijalankan secara adil dan bertanggung jawab dan Indonesia sebagai kekuatan ekonomi baru yang bangkit, sebagai negara berpenduduk muslim terbesar di muka bumi, sebagai negara demokrasi terbesar ketiga dunia, siap memainkan peran global sebagai kekuatan positif bagi perdamaian dan kesejahteraan (KAA).

(26) Melalui forum ini saya ingin menyampaikan keyakinan saya bahwa masa depan dunia ada di sekitar ekuator, di tangan kita. Bangsa-bangsa Asia-Afrika yang ada di dua benua (KAA).

Pada data (25) dan (26) Jokowi tampak berbasa-basi dan mengundang presuposisi dari audiensinya. Secara pragmatis, Jokowi ingin menunjukkan bahwa Indonesia adalah negara yang memenuhi kualifikasi yang dibutuhkan untuk memimpin dunia mewujudkan cita-cita KAA.

\section{Realisasi Strategi Menggunakan Lelucon}

Realisasi strategi retorika positif menggunakan lelucon dalam pidato Presiden Jokowi berkonteks diplomasi luar negeri tampak pada data (27).

(27) Inilah kesempatan, kesempatan kerja sama pengusaha Indonesia dan pengusaha dari Tiongkok. Harus kerja sama, agar ada percepatan. Bapak-Ibu bisa melihat, ya kita bandingkan saja, sekarang upah pekerja di sini berapa? Di Indonesia berapa? Kalau saya buka di sini, pengusaha di sini bisa lari semuanya ke Indonesia karena kita jauh lebih kompetitif. Oleh sebab itu, saya kira pengusaha bisa menyampaikan betapa kita mempunyai sebuah ruang kompetisi untuk membawa industri kita berkembang lagi. Dunia manufaktur kita juga berkembang lagi.

Untuk memberikan penekanan informasi bahwa upah pekerja Indonesia kurang kompetitif, Jokowi tampak mengemasnya dalam sebuah lelucon sebagaimana tampak pada data (27). Jokowi tidak secara lugas mengungkap kurang kompetitifnya upah pekerja Indonesia disebabkan kelemahan bangsanya. Ia tidak ingin secara vulgar mempermalukan bangsanya sendiri. Strategi menggunakan lelucon ia pilih karena topik ini adalah salah satu magnet untuk menarik calon investor ke Indonesia. Jokowi yakin para calon investornya sudah mengetahui perihal itu sehingga ia tidak menyampaikannya secara jelas dan eksplisit.

\section{Realisasi Strategi Memberikan Tawaran atau Janji}

Realisasi strategi retorika positif memberikan tawaran atau janji dalam pidato Presiden Jokowi berkonteks diplomasi luar negeri tampak pada data (28) sampai dengan (30).

(28) Ini problem besar yang harus kita selesaikan dan saya, sudah saya mulai agar izin-izin ini nanti akan kita gabungkan dalam sebuah kantor one stop service, yang kita harapkan nanti semua kementerian baik PLN, kantor ESDM yang urusan-urusan yang berkaitan dengan investasi berada dalam satu gedung, dalam satu ruangan sehingga ngurusngurus izin itu gampang, tidak bertahun-tahun seperti yang sekarang kita lihat. Kemarin yang di Sumatera Selatan, saya telepon, 
seminggu selesai, tapi masa tiap hari presiden harus telepon urusan izin? Ini tidak mungkin (APEC).

(29) Saya tunggu kedatangannya di Indonesia. Saya tunggu investasinya di Indonesia (APEC).

Pada data (28) dan (29), tampak Jokowi menggunakan strategi retorika memberikan tawaran atau janji pada audiensinya. Pada data (28) Jokowi memberi janji kemudahan perizinan, sedangkan pada data (29) Jokowi mengajak atau memberikan tawaran untuk datang dan berinvestasi di Indonesia.

(30) Indonesia siap bekerjasama dengan semua pihak untuk wujudkan citacita mulia itu (KAA).

Pada data (30), Jokowi secara eksplisit menawarkan kerja sama dengan negara-negara yang memiliki cita-cita yang sama, mewujudkan cita-cita KAA. Sebagai tuan rumah KAA, dia sangat tahu ini kesempatan emas mengambil peran lebih banyak dan lebih aktif.

\section{Realisasi Strategi Menunjukkan Keoptimisan}

Realisasi strategi retorika positif menunjukkan keoptimisan dalam pidato Presiden Jokowi berkonteks diplomasi luar negeri tampak pada data (31) sampai dengan (33).

(31) Juga di beberapa lokasi, kita ingin membangun sebuah industrial zone karena kita ingin industri kita berkembang lagi. Manufaktur di Indonesia juga berkembang lagi. Sekian tahun ini industri kita turun. Bukan naik, tapi turun, deindustrialisasi. Ke depan, saya meyakini-karena saya juga berasal dari dunia industri-saya tahu apa yang harus saya kerjakan. Saya tahu apa yang harus negara kerjakan untuk membangun industri di Indonesia lagi (APEC).

(32) Hari ini dan hari esok, dunia menanti langkah-langkah kita dalam membawa bangsa-bangsa AsiaAfrika berdiri sejajar sama tinggi dengan bangsa-bangsa lain di dunia. Kita bisa melakukan itu semua dengan membumikan "Semangat Bandung" dengan mengacu pada tiga cita-cita yang diperjuangkan para pendahulu kita enam puluh tahun lalu (KAA).

(33) Melalui forum ini, saya ingin menyampaikan keyakinan saya bahwa masa depan dunia ada di sekitar ekuator, di tangan kita. Bangsa-bangsa Asia-Afrika yang ada di dua benua (KAA).

Pada data (31) dan (33), tampak Jokowi menggunakan strategi yang dapat menunjukkan keoptimisannya. Salah satu penanda lingual yang dia gunakan adalah dengan menggunakan modalitas epistemik 'yakin'. Penggunaan modalitas epistemik dapat memperkuat keyakinan audiensi terhadap apa yang disampaikan oleh penutur, bahkan pada data (32) dia optimis negara-negara anggota KAA bisa mewujudkan cita-cita dirumuskan enam puluh tahun yang lalu.

\section{Realisasi Strategi Melibatkan Penutur dan Pendengar dalam Aktivitas}

Realisasi strategi retorika positif melibatkan penutur dan pendengar dalam aktivitas dalam pidato Presiden Jokowi berkonteks diplomasi luar negeri tampak pada data (34) dan (35).

(34) Ini problem besar yang harus kita selesaikan dan saya, sudah saya mulai agar izin-izin ini nanti akan kita gabungkan dalam sebuah kantor one stop service, yang kita harapkan nanti semua kementerian baik PLN, 
kantor ESDM yang urusan-urusan yang berkaitan dengan investasi berada dalam satu gedung, dalam satu ruangan sehingga ngurusngurus izin itu gampang, tidak bertahun-tahun seperti yang sekarang kita lihat. Kemarin yang di Sumatera Selatan, saya telepon, seminggu selesai, tapi masa tiap hari presiden harus telepon urusan izin? Ini tidak mungkin (APEC).

(35) Tetapi kalau investor didukung oleh pemerintah ini sebenarnya hal yang sangat mudah. Kenapa? Karena biasanya investor dibiarkan sendiri kalau ada masalah. Tidak pernah dibantu (APEC).

Pada data (34) dan (35), tampak Jokowi berusaha keras untuk mengajak audiennya untuk terlibat langsung dalam komunikasi meskipun dia menyadari bahwa pidatonya hanyalah komunikasi satu arah. Salah satu bentuk upaya Jokowi adalah dengan menyelipkan pertanyaan di tengah menyampaikan data atau permasalahan. Strategi ini sangat baik dilakukannya untuk tetap menjaga perhatian dan atensi pendengarnya.

\section{Realisasi Strategi Memberikan Pertanyaan atau Meminta Alasan}

Realisasi strategi retorika positif memberikan pertanyaan atau meminta alasan dalam pidato Presiden Jokowi berkonteks diplomasi luar negeri tampak pada data (36) dan (37).

(36) Ini problem besar yang harus kita selesaikan dan saya, sudah saya mulai, agar izin-izin ini nanti akan kita gabungkan dalam sebuah kantor one stop service, yang kita harapkan nanti semua kementerian baik PLN, kantor ESDM yang urusan-urusan yang berkaitan dengan investasi berada dalam satu gedung, dalam satu ruangan, sehingga ngurusngurus izin itu gampang, tidak bertahun-tahun seperti yang sekarang kita lihat. Kemarin yang di Sumatera Selatan, saya telepon, seminggu selesai. Tapi masa tiap hari presiden harus telepon urusan izin? Ini tidak mungkin (APEC).

(37) Tetapi kalau investor didukung oleh pemerintah ini sebenarnya hal yang sangat mudah. Kenapa? Karena biasanya investor dibiarkan sendiri kalau ada masalah. Tidak pernah dibantu (APEC).

Meski pidato merupakan komunikasi satu arah, tetapi Jokowi mampu menunjukkan kemampuan retorika yang baik dengan menyelipkan beberapa pertanyaan yang bersifat retoris kepada audiensinya seperti tampak pada data (36) dan (37).

\section{Realisasi Strategi Memberikan Hadiah (Barang, Simpati, Perhatian, Kerja Sama) Kepada Pendengar}

Realisasi strategi retorika positif memperhatikan kesukaan, keinginan, dan kebutuhan pendengar dalam pidato Presiden Jokowi berkonteks diplomasi luar negeri tampak pada data (38) sampai dengan (39).

(38) Oleh sebab itu, yang paling penting adalah membangun sebuah kantor perizinan, yang nanti akan saya pantau langsung dan kemudian kalau Bapak/Ibu semuanya mendapatkan kesulitan, ya, itu baru saya yang menyelesaikan. Problem kita emang ada di situ. Saya bercerita karena saya pernah mengalami ngurus izin. Tinggal kita harapkan ke depan tidak ada lagi urusan-urusan yang berkaitan dengan listrik. Kita ingin sekarang ini memulai power plant dibangun, industri juga dibangun. Power plant- 
nya selesai, industrinya juga selesai. Ini yang ingin kita kerjakan ke depan (APEC).

Jokowi tampak memberi perhatian yang serius perihal perizinan dalam berinvestasi. Bentuk "hadiah" yang diberikan Jokowi adalah berupa keseriusan dalam memangkas birokrasi perizinan, bahkan dia akan membantu menyelesaikan masalah perizinan jika dialami para calon investor dari Tiongkok sebagaimana tampak pada data (38).

(39) Saat ini dunia membutuhkan kepemimpinan global yang kolektif, yang dijalankan secara adil dan bertanggung jawab dan Indonesia sebagai kekuatan ekonomi baru yang bangkit, sebagai negara berpenduduk muslim terbesar di muka bumi, sebagai negara demokrasi terbesar ketiga dunia, siap memainkan peran global sebagai kekuatan positif bagi perdamaian dan kesejahteraan.

(40) Indonesia akan bekerja menjadi jembatan maritim yang menghubungkan kedua benua (KAA).

Pada data (39) dan (40), Jokowi ingin Indonesia tampil di depan. Ia menawarkan Indonesia jembatan maritim dua benua, yaitu Asia dan Afrika. Pada konteks ini, Jokowi sedang mempraktikkan strategi memberikan hadiah kepada audiensinya.

\section{PENUTUP}

Gaya pidato Jokowi, khususnya dalam mempersuasi investor dari Tiongkok dan pimpinan negara KAA, dari sudut pandang kebahasaan memiliki dua pesan, yakni pesan yang dinyatakan secara lugas dan tersamar. Dua jenis pesan itu digunakan secara bergantian sesuai kebutuhan pragmatis penuturnya.
Untuk dapat mempersuasi dan merebut simpati audiensinya, Jokowi memainkan strategi dan metode berpidato yang secara pragmatis memenuhi kaidah strategi kesantunan positif yang dikembangkan oleh Brown dan Levinson (1987). Dari lima belas strategi kesantunan positif yang dikembangkan oleh Brown dan Levinson, Presiden Jokowi mampu menggunakan tiga belas substrategi kesantunan positif. Artinya, anggapan awam bahwa Jokowi bukan politikus yang pandai bicara tampak terbatahkan. Jokowi seorang figur pemimpin yang dibesarkan dari kalangan bawah, tetapi spontanitasnya dalam beretorika di depan publik mampu mengantarkan kedekatan dan menimbulkan efek kemenyatuan dengan pendengarnya.

\section{DAFTAR PUSTAKA}

Asmara, R. (2016). Strategi kebahasaan Presiden Jokowi dalam menanamkan ideologi dan manifesto pemerintahan. Litera, 15(2), 379-388.

Asmara, R., Kusumaningrum, W. R., \& Fortinasari, Paulina Besty, $\mathrm{H}$. (2020). How does a celebrity politician's diction attract public empathy for parliamentary election? A critical discourse analysis. International Conference on Language and Language Teaching, 1-6.

Asror, A. G. (2015). Bahasa pencitraan dalam iklan kampanye pilkada Kabupaten Bojonegoro. Magistra, XXVII(92), 24-34.

Asror, A. G. \& Sholehhudin, M. (2016). Analisis bahasa pencitraan iklan politik pilkada Kabupaten Tuban tahun 2015. PEDAGOGIA: Jurnal Pendidikan, 5(2), 197. 
Brown, P., \& Levinson, S. C. (1987). Politeness: Some universals in language usage. Cambridge: Cambridge University Press.

Huberman, A. \& Miles, M. (2012). Understanding and validity in qualitative research. In The Qualitative Researcher's Companion, 36-64.

Kridalaksana, H. (2008). Kamus linguistik. Jakarta: Gramedia Pustaka Utama.

Kusmanto, H., Prayitno, H. J., \& Ngalim, A. (2019). Realisasi tindak kesantunan berbahasa pada komentar akun Instagram Jokowi: Studi politikopragmatik. Kandai, 15(1), 47-60.

Luhukay, M. S. (2007). Presiden SBY dan politik pencitraan: Analisis teks pidato Presiden SBY dengan pendekatan retorika Aristoteles. Scriptura, 1(2).

Nasiha, N. F. \& Yunaldi, A. (2019). Representasi kecantikan dalam iklan Slimmewhite (Studi wacana Sara Mills). Al-MUNZIR, 12(1), 165.
Noermanzah, N., Emzir, E., \& Lustyantie, N. (2017). Variety of rhetorics in political speech President of The Republic of Indonesia Susilo Bambang Yudhoyono and Joko Widodo in educational field. Humanus, 16(2), 221-238.

Rindu, D. S. (2017). Analisis wacana kritis Van Dijk dalam teks berita "Bayi berkepala dua lahir di Cilacap."Deiksis: Jurnal Pendidikan Bahasa Dan Sastra Indonesia, 4(1), 119-130.

Sobur, A. (2006). Analisis teks media: Suatu pengantar untuk analisis wacana. Bandung: PT Remaja Rosdakarya.

Sulistyaningtyas, T. (2009). Bahasa Indonesia dalam wacana propaganda politik kampanye Pemilu 2009, Satu kajian sosiopragmatik. Jurnal Sosioteknologi, 8(17), 637-645.

Sulityaningtyas, T., Suganda, D., Sobarna, C., \& Wahya, W. (2014). Representation of legislative member candidates of Partai Demokrat on their outdoor political advertising. International Journal of Linguistics, 6(2), 286-297. 